\title{
LEWENSKWALITEIT TE MIDDE VAN 'n ERGE STRESSOR: ' $n$ STUDIE VAN BEJAARDES MET ALZHEIMER SE SIEKTE OF RUMATOÏEDE ARTRITIS
}

\author{
Pieter M Heyns \\ D Phil \\ Professor, Departement Sielkunde, Universiteit van die Vrystaat \\ Korresponderende outeur: heynsm@hum.uovs.ac.za.
}

\author{
Michelle Viljoen \\ M Sc (Kliniese Sielkunde) \\ Kliniese Sielkundige SANW
}

\section{Dirk C Odendaal \\ M Soc Sc; MBL \\ Lektor, Universiteit van die Vrystaat}

Sleutelterme: Lewenskwaliteit; psigofortologie; bejaardheid; rumatö̈ede artritis; Alzheimer se siekte

\section{OPSOMMING}

Hierdie studie handel oor die rol wat psigofortigene faktore speel in die handhawing van lewenskwaliteit deur bejaardes wat gediagnoseer is met rumatoïede artritis of Alzheimer se siekte. Psigofortigenese het te make met die sielkundige faktore wat sielkundige sterktes in die teenwoordigheid van stressore onderlê. Lewenskwaliteit word, teen die agtergrond van die onderskeiding tussen ' $n$ hedonistiese en eudaimoniese perspektief, gedefinieer as die subjektiewe ervaring van 'n suksesvolle strewe na die bereiking van belangrike doelwitte. Die ondersoekgroep het bestaan uit 14 bejaardes woonagtig in ' $n$ ouetehuis of ' $n$ aftree-oord. Die ondersoekgroep is in drie groepe verdeel, een met rumatoïede artritis, een met Alzheimer se siekte en 'n derde groep relatief gesonde bejaardes. Hierdie artikel fokus op die kwalitatiewe ontleding van ongestruktureerde onderhoude met die bejaardes. 'n Ontleding van die resultate het ' $n$ belewenis van welstand by hulle aangedui. Die rol van hulle persepsie van lewensgebeure as verstaanbaar, beheerbaar en betekenisvol, die drie elemente van Antonovsky se Koherensiesin, is toegelig. Volgens die ondersoek het ' $n$ sosiale ondersteuningsnetwerk en ' $n$ spirituele geloofsisteem ook betekenisvol bygedra tot die handhawing van hulle lewenskwaliteit.

\section{SUMMARY}

This study addresses the role of psychofortigenic factors in maintaining quality of life in elderly people diagnosed with either rheumatoid arthritis or Alzheimer's disease. Psychofortigenesis pertains to psychological factors underlying psychological strengths in the presence of stressors. Quality of life is defined, with the distinction between a hedonistic and eudaimonic perspective as backdrop, as the subjective experience of a process of successful striving towards achieving important goals. The subjects were 14 elderly people residing in either an old age home or a retirement village. Three subgroups were studied, one group diagnosed with Alzheimer's disease, one group with rheumatoid arthritis and another group of relatively healthy elderly persons. A qualitative analysis of interviews with the subjects confirmed their general sense of well-being. The role of their perception of life events as comprehensible, manageable and meaningful, the three elements of Antonovsky's Sense of Coherence, is highlighted. According to the study a supportive social network and a spiritual belief system also contributed significantly to maintenance of their quality of life. 


\section{INLEIDING}

Elke mens word van tyd tot tyd aan een of ander buitengewone stressor onderwerp. Die identifisering van faktore wat ' $n$ mens help om in sodanige omstandighede goeie lewenskwaliteit te handhaaf, is dus van besondere belang. Alzheimer se siekte en rumatoïede artritis is erge stressore wat dikwels bejaardes se lewenskwaliteit bedreig. Hierdie studie het ten doel gehad om die handhawing van lewenskwaliteit te midde van hierdie stressore by bejaardes onder oë te neem.

Die definisies van lewenskwaliteit mag verskil, maar dit word dikwels met goeie gesondheid geassosieer. Gesondheid, en selfs geestesgesondheid, is ook vir baie jare bloot beskou as ' $n$ toestand gekenmerk deur die afwesigheid van liggaamlike of geestesiekte. Daar het egter in dié verband in die sielkunde, veral in die afgelope dekade, ' $n$ bykans dramatiese kentering gekom. In hierdie nuwe benadering, wat as die positiewe sielkunde bekend staan, word daar geworstel met vrae oor die werklike aard van konstrukte soos optimale sielkundige gesondheid, sielkundige volwassenheid, sielkundige welstand, veerkragtigheid en lewenskwaliteit (Seligman \& Csikszentmihalyi, 2000:514).

Die konstruk 'welstand' (well-being) geniet veral tans heelwat aandag. Ryan en Deci (2001:141-166) beskou welstand as ' $n$ komplekse begrip wat in verband staan met optimale ervarings en funksionering. Volgens hulle is daar tans twee algemene perspektiewe aan die orde van die dag naamlik: a) die hedonistiese perspektief wat op geluk fokus en welstand definieer in terme van plesier en pynvermyding en b) die eudaimoniese perspektief wat op betekenis en selfverwesenliking fokus. ' $n$ Eudaimoniese lewensbenadering dui op ' $n$ persoon wat sy of haar innerlike waardes en oortuigings en dus die eie ware self (of daimon) ten volle uitleef (Waterman, 1993:678-691).

Ofskoon hedonie histories 'n negatiewe konnotasie het, geassosieer met geluk wat uit ' $n$ oppervlakkige plesiersoekery voortspruit, word dit in die konteks van die navorsing oor welstand geïnterpreteer as geluk wat verkry word uit die bereiking van doelwitte en uitkomste wat hoog getakseer word (Diener, Sapyta \& Suh, 1998:33-37). Die eudaimoniese perspektief kritiseer egter die hedonistiese perspektief omdat nie alle uitkomste wat 'n persoon nastreef, welstand tot gevolg het nie. Eudaimonie, 'n konsep waarvan Aristoteles die vader is, assosieer welstand met die uitlewing van 'goedheid', om dus dít te doen wat moreel reg is en die moeite werd is om te doen (Strümpfer, 2003). Dit geskied wanneer ' $n$ persoon se aktiwiteite kongruent met diepgesetelde waardes en holisties geïntegreerd is.

Die hedoniese perspektief staan dus in verband met begrippe soos 'lewenstevredenheid' en 'lewensgeluk' terwyl die eudaimoniese perspektief 'betekenisvolheid' beklemtoon.

Die selfdeterminasie-teorie van Ryan en Deci (2000:6878) sluit by die eudaimoniese perspektief aan. Dit koppel sielkundige welstand aan die vervulling van drie basiese behoeftes te wete outonomie, bekwaamheid en om in verhoudings te staan. Hierdie teorie onderstreep die belangrikheid van behoeftevervulling as ' $n$ primêre lewensdoel wat baie van die betekenisse en doelstellings van menslike handelinge onderlê.

Op grond van die verskillende perspektiewe op welstand meen Ryan en Deci (2001:141-166) tereg dat welstand ' $n$ multidimensionele fenomeen is wat beide hedoniese en eudaimoniese elemente, te wete elemente van 'geluk' en 'betekenis' insluit en dat heelwat navorsing nog nodig is om dit te differensieer.

Die volgende definisie van lewenskwaliteit, oftewel sielkundige welstand, word dus aan die hand gedoen: Lewenskwaliteit is ' $n$ subjektiewe ervaring van welstand en tevredenheid wat bewerkstellig word deur tevredenheid oor wat in die verlede bereik en ervaar is, deur tans (hede) ervarings te hê wat harmonieer met belangrike lewenswaardes asook deur die ervaring dat daar doeltreffend gestreef kan word na realistiese eie doelwitte van 'n hoë 'waarheidsgehalte' (toekoms).

Aanverwant aan die vraag oor wat die kernelemente van 'lewenskwaliteit' uitmaak, is ook die vraag wat dit is wat ' $n$ persoon staande hou te midde van stressore. Konstrukte soos veerkragtigheid (resilience) (Glantz \& Johnson, 1999; Kumpfer, 1999; Strümpfer, 2003) en salutogenese en koherensiesin (Antonovsky, 1979, 1987) probeer antwoorde hierop bied.

Volgens Antonovsky stel 'n koherensiesin (sense of 
coherence) 'n persoon in staat om terugslae te bowe te kom en stressore suksesvol te kan hanteer. ' $n$ Koherensiesin word beskou as ' $n$ gesindheidsoriëntasie met kognitiewe, emosionele en motiveringselemente. Dit omvat ' $n$ ingesteldheid om omgewingstimuli (stressore) waar te neem as a) verstaanbaar, naamlik dat dit op kognitiewe vlak sin maak; b) beheerbaar, naamlik onder eie kontrole of onder die beheer van betekenisvolle 'ander' soos byvoorbeeld die eggenoot, vriende, gesagsfigure of God; en c) betekenisvol sodat dit ' $n$ motiverende appèl rig om die situasie as ' $n$ uitdaging te beskou en die moeite werd geag word om daarby betrokke te raak (Antonovsky, 1979, 1987).

Strümpfer (1995:81-89) het egter die konstruk 'salutogenese' uitgebrei om dit nie net op fisieke gesondheid van toepassing te maak nie, soos Antonovsky dit oorspronklik in gedagte gehad het nie, maar op sielkundige krag of sterkte in die algemeen. Hy gebruik daarom die term 'fortigenese' (Latyn: fortis = sterkte). Wissing en Van Eeden (1998:379-393) gaan ' $n$ stap verder en skep die term 'psigofortologie' (psychofortology) wat op die wetenskap van sielkundige sterktes dui.

' $n$ Verdere vraag is watter faktore hierdie sielkundige sterktes onderlê en onderhou. Antonovsky (1979) beklemtoon in dié verband die sogenaamde algemene weerstandshulpbronne wat die vermyding of hantering van ' $n$ verskeidenheid stressore fasiliteer. Goeie gesondheid, materiële hulpmiddele, 'n goeie intelligensie, ' $n$ goeie selfbeeld, gesonde waardes en houdings, spirituele faktore en ' $n$ sosiale ondersteuningsnetwerk is voorbeelde van sodanige weerstandshulpbronne.

Hierdie studie fokus op bejaardes met Alzheimer se siekte of rumatoïede artritis se handhawing van hulle lewenskwaliteit. Bejaardheid as sodanig kan egter ook ' $n$ bedreiging vir lewenskwaliteit inhou. Ryan en Deci (2001:141-166) verwys in dié verband na die paradoks van veroudering. Ten spyte van bejaardes se vele verlieservarings en nuwe (dikwels onoorkomelike) uitdagings, is die getuienis egter dat hulle gevoel van subjektiewe welstand toeneem (Carstensen, 1998:341346, Mroczek \& Kolarz, 1998:1333-1349). Die fokus van behoeftes verskuif egter met die ouderdom. Terwyl alle ouderdomsgroepe waarde heg aan basiese sielkundige behoeftes soos goeie interpersoonlike verhoudings en aangename aktiwiteite, is die suksesvolle hantering van verandering en die betekenis of diepte van ervarings vir die bejaarde belangrik. Jeugdiges daarenteen, fokus meer op verbredende ervarings soos meer selfkennis, meer bekwaamheid en groter selfaanvaarding (Carstensen, 1998:341-346; Diener \& Lucas, 2000:325-337; Ryff, 1989:195-210, 1991:286-295; Ryan \& La Guardia, 2000:145-172).

Die vraag kan vervolgens gestel word hoe psigofortigene faktore op lewenskwaliteit inspeel wanneer daar erge stressore, soos Alzheimer se siekte of rumatoïede artritis, by bejaardes teenwoordig is.

Alzheimer se siekte kan beskryf word as ' $n$ progressiewe, neuro-degeneratiewe versteuring met ' $n$ stadige aanvangstempo gevolg deur ' $n$ geleidelike deteriorasie in korttermyngeheue, intellektuele en kognitiewe funksionering en algemene funksionele vermoëns (Edwards, Boucher, Haslett \& Chilvers, 1995). Die DSM IV (American Psychiatric Association, 1994) se diagnose van Alzheimer se siekte wys op die ontwikkeling van veelvuldige kognitiewe inkortings wat oor tyd heen na vore tree, asook die inperking van uitvoerende funksies soos beplanning en organisering. Dit lei onvermydelik ook tot inkorting van die persoon se sosiale en beroepsfunksionering en uiteindelik tot die dood.

Uiteraard het ' $\mathrm{n}$ diagnose van Alzheimer se siekte katastrofale implikasies vir die pasiënt en veral ook vir sy of haar versorger. Daar word bereken dat meer as die helfte van die versorgers van pasiënte met demensie, gewoonlik huweliksmaats, kinders en ander familielede, uiteindelik klinies depressief raak (George, 1984:261).

' $n$ Ander siekte met erge funksioneringsimplikasies vir die pasiënt is rumatoïede artritis. Rumatoïede artritis (RA) is ' $n$ kroniese, sistemiese, progressiewe, inflammatoriese siekte van die sinoviale gewrigte en kom algemeen voor in die perifere gewrigte, byvoorbeeld die hande en voete, maar kan ook die bindweefsel in die oë, longe en bloedvate aantas (Beare \& Myers, 1994). Die pasiënt ervaar in die siekte se akute fase aanhoudende pyn vanweë die gewrigsontsteking. Die kroniese verloop van die siekte het ook ' $n$ ernstige sielkundige uitwerking op die pasiënt, veral vanweë versteurde slaappatrone, moegheid, inkorting van beweging en selfbeeldversteurings as gevolg van 
gewrigsvervorming (Beare \& Myers, 1994; Viljoen, 2000).

Whalley, McKenna, De Jong en Van der Heijde (1997:884-888) het in ' $n$ ondersoek na die lewenskwaliteit van die rumatoïede-artritispasiënt gevind dat pasiënte se ingeperkte beweeglikheid gelei het tot ' $n$ groter mate van afhanklikheid van ander mense en 'n gevolglike gevoel van hulpeloosheid. Emosies van frustrasie, woede en depressie het ook algemeen voorgekom.

Beide Alzheimer se siekte en rumatoïede artritis is dus erge stressore wat die potensiaal het om die lewenskwaliteit van bejaardes intens te bedreig. Die vraag is vervolgens hoe psigofortigene faktore, veral dié geïdentifiseer deur Antonovsky (1979, 1987), sodanige bejaardes in staat stel om hulle lewenskwaliteit te behou.

\section{DOEL EN METODE VAN DIE ONDER- SOEK}

Die doel van hierdie studie was ' $n$ ondersoek van die rol van psigofortigene faktore by die behoud van lewenskwaliteit by bejaardes gediagnoseer met Alzheimer se siekte of rumatoïede artritis, met spesiale verwysing na die psigofortigene faktore wat deur Antonovsky $(1979,1987)$ identifiseer is.

Die ondersoek was van ' $n$ kwalitatiewe aard. Kwalitatiewe metodologie kan as verkennendbeskrywend beskryf word en fokus gewoonlik op die unieke betekeniskonstruksies van die navorsingsubjekte (Patton, 1990). In hierdie ondersoek is die daaglikse subjektiewe lewenservaringe van die ondersoekgroep onder oë geneem. 'n Gevallestudie-benadering gerig op ' $n$ indiepte-begrip is derhalwe gevolg (Berg, 1995). Die benadering is van pas aangesien min kandidate in veral die vroeë fase van Alzheimer se siekte beskikbaar is.

\section{Die ondersoekgroep}

Die ondersoekgroep het bestaan uit 14 hoofsaaklik middelklas Afrikaanssprekende (een was Engelssprekend) blanke bejaardes. Die jongste was 72 jaar oud en die oudste 88 jaar. Hulle was almal in Bloemfontein woonagtig, óf in ' $n$ aftree-oord bestaande uit selfversorgende wooneenhede óf in ' $n$ tehuis vir bejaardes waarin hulle voltydse versorging gekry het.
Slegs een was manlik (getroud). Een dame was getroud en een was geskei. Die res was weduwees.

Die mediese personeel betrokke by die aftree-oord en tehuis vir bejaardes het meegewerk om die ondersoekgroep te identifiseer en vir deelname aan die studie te nader. Deelname aan die ondersoek was op ' $n$ vrywillige grondslag en anonimiteit is gewaarborg. Die ondersoekgroep is in drie groepe onderverdeel. Een groep was gediagnoseer met Alzheimer se siekte $(n=5)$, ' $n$ ander groep $(n=5)$ het rumatoïede artritis gehad en ' $n$ derde groep $(n=4)$ was, sover bekend aan die mediese personeel van die inrigtings, vry van enige siekte wat hulle funksionering ernstig belemmer het.

Praktiese oorwegings het die grootte van die ondersoekgroep beperk. Diegene wat aan Alzheimer se siekte gely het, moes steeds in " $n$ vroeë fase van die siekte gewees het om onderhoudvoering moontlik te maak en slegs vyf persone het aan hierdie kriterium voldoen. Daar is nietemin seker gemaak dat ' $n$ dataversadigingspunt wel bereik is en dat die bybring van meer persone onwaarskynlik nuwe inligting sou oplewer. Die verkennende resultate van kwalitatiewe studies, tradisioneel op klein steekproewe gebaseer vanweë die intensiewe aard van die ontledingsproses, moet egter altyd met omsigtigheid hanteer word.

\section{Data-insamelingstegnieke en data- ontledingsprosedures}

Ongestruktureerde onderhoude van ongeveer 90 minute is deur een van die navorsers (MV) met al die lede van die ondersoekgroep gevoer. Die bejaarde is uitgevra na sy of haar lewensverhaal. Die navorser het in hierdie oop gesprek faktore wat met lewenskwaliteit verband hou probeer identifiseer en waar nodig, verdere vrae ter opheldering gevra.

Die ontleding van die getranskribeerde onderhoude het geskied aan die hand van die riglyne verskaf deur onder meer Miles en Hubermann (1994) en die gegronde teorie (grounded theory) soos beskryf deur Strauss en Corbin (1998). Die ontledingsproses het dus berus op die kodering en indeksering van betekenisvolle dataelemente en die soeke na onderliggende temas en patrone. Waar Strauss en Corbin (1998) egter die dataontledingsproses vanuit ' $n$ suiwer fenomenologiese uitgangspunt benader is die kernkonstrukte van die 
psigofortologie en die lewenskwaliteitliteratuur in hierdie ondersoek in die koderingsproses verreken.

Die NUD*IST-rekenaarprogram (NUD*IST, 1999) is in die ontledingsproses as administratiewe hulpmiddel benut. Die "Non-numerical, Unstructured Data Indexing, Searching and Theorizing" (NUD*IST) sagtewarerekenaarprogram is juis vir die doel ontwikkel en vergemaklik by nie-numeriese ongestruktureerde data die proses van kodering, indeksering en uiteindelike teoretisering.

Vertrouenswaardigheid van die resultate speel by kwalitatiewe navorsing die rol wat geldigheid en betroubaarheid by kwantitatiewe metings speel (Patton, 1990:464). Hierdie vertrouenswaardigheid kan ondermeer deur triangulasie bekom word. Triangulasie van data is in hierdie ondersoek bekom deur die benutting van data afkomstig van drie verskillende ondersoekgroepe. Triangulasie van ontledings is bewerkstellig deur die kritiese insette van die verskillende outeurs van hierdie ondersoek in die ontledingsproses. Triangulasie van navorsingsmetodes is nagestreef deur die toepassing van psigometrie op die ondersoekgroep. Die resultate van hierdie kwantitatiewe ondersoek is egter elders beskryf (Viljoen, 2000). Vertrouenswaardigheid kan ook bevorder word deur die doelgerigte ondersoek van sogenaamde negatiewe gevalle. Sodanige gevalle se data staan in kontras met die patrone en tendense wat uit die res van die resultate spreek, maar kan juis benut word om die sterkte van die geïdentifiseerde patrone te toets. Dit gaan dus oor die vind van uitsonderings wat die reël bevestig (Patton, 1990:463). Nietemin is kwalitatiewe navorsing, vanweë die subjektiewe aard daarvan, gewoonlik slegs verkennend van aard en lewer dit tentatiewe resultate op wat met omsigtigheid hanteer moet word hoewel dit ryk aan betekenisinhoud kan wees.

\section{RESULTATE}

Die volgende temas wat in die ontleding van die gespreksdata na vore gekom het sal vervolgens bespreek word: Eerstens sal die impak van die siektes op die bejaardes in die algemeen, maar veral ook op hulle ervaring van lewenstevredenheid, onder oë geneem word. Daarna sal die rol van die psigofortigene faktore in die behoud van ' $n$ ervaring van hoë lewenskwaliteit ontleed word met spesifieke verwysing na die rol van die drie elemente van ' $n$ koherensiesin naamlik, verstaanbaarheid, hanteerbaarheid en betekenisvolheid. Die betekenis van die neiging van die bejaardes om hulle siekte te relativeer sal kortliks aangeraak word waarna die rol van weerstandshulpbronne vir die handhawing van lewenskwaliteit bespreek sal word.

\section{Impak van die siektes}

Die siektes waarmee hierdie bejaardes gediagnoseer is, is gewis as erge stressore ervaar. Die inperkende effek wat kognitiewe inkorting in bejaardes met Alzheimer se siekte te weeg bring kom duidelik na vore in die volgende aanhalings: "You just sometimes can't remember ordinary things that you know very well...". "Jong as ek sien ek kan dit nie behartig nie, dan vertel ek vir haar (eggenote); ek kry hulp of sy vat my na ' $n$ plek waar ek hulp kry".

Die pynlike saamleef met rumatoïede artritis eis ook sy tol: "Die pyn vreet my nou op. Dit voel ek kan soos 'n klein kindjie staan en skree". "Jy kan nie meer doen wat jy gedoen het nie, dan raak jy natuurlik 'n bietjie gefrustreerd, soos party dae het ek nie die krag om 'n koeldrankbottel oop te draai nie, dan word jy maar half opstandig".

\section{Aanduidings van lewenstevredenheid}

Ten spyte van die teenwoordigheid van bogenoemde stressore, was dit opvallend dat bykans al die bejaardes in hierdie ondersoek te kenne gegee het dat hulle wel lewenstevredenheid ervaar. (Die diagnose van die betrokke bejaarde word telkens soos volg tussen hakies aangedui: A - bejaardes wat aan Alzheimer se siekte ly; R - bejaardes met rumatoïede artritis; G - gesonde bejaardes). "We had a hard life, but it turned out all right ... I am quite happy" (A). "As ek my lewe kon oorkry, dan is daar miskien 'n paar punte wat ek definitief sou wou verbeter, maar ek kan regtig nie kla nie" (R). "Ek is baie gelukkig, daar is nie klagtes nie, ons pas goed aan" $(\mathrm{G})$.

Daar is sterk aanduidings dat die voorsiening in basiese behoeftes ' $n$ belangrike bydrae tot die lewenstevredenheid lewer: "... ek kry 'n redelike pensioen, ons kan ordentlik lewe, ek is eintlik bly ... " (A). "Nee, dit was 'n lekker ou lewetjie gewees wat ek 
tot dusver gehad het, want ek het nou 'n seun wat baie vir my omgee" $(\mathrm{A})$.

Die uitlewing van eie belangstellings en die realisering van eie potensiaal in die verlede en hede speel klaarblyklik 'n belangrike rol: “... ek het maar al die dinge gedoen wat ek wou, ek is universiteit toe, ek het my graad gekry, en het gewerk en uhm, toe getrou ... ek het min of meer gedoen wat ek wou in die omstandighede, jy weet" (A). "Ag, nee ek het nou genoeg gelewe, ek verlang nie om so oud soos tannie Sannie te word nie, mens voel as jy klaar is, is jy klaar ... ek het my kinders grootgemaak, twee van my kleinkinders al gesien trou en ek het sewe van hulle, nee wat ek is doodtevrede" $(\mathrm{R})$.

Die afwesigheid van belemmerde faktore is ook ' $n$ bron van dankbaarheid: "Weet jy ek kry nooit, nooit hoofpyn nie, ek het geen pyn van ' $n$ aard nie. Al wat ek het is: ek is bietjie onvas op my voete en die gehoor, maar wat my eetgewoontes betref, ek slaap soos ' $n$ bom. As ek gaan lê in die aand weet ek nie hoekom ek so gelukkig is nie ..." (G).

Die aanduidings was dat hierdie opmerkings eerlik en openhartig was want waar een van die bejaardes wel ontevrede was het sy sonder skroom daaraan uitdrukking gegee. Die betrokke dame se ongelukkigheid sentreer om die gebrek aan lewensmiddele: "As jou kinders jou nie help nie, of jy besonders goed nagelaat is nie, kan jy nie hier leef nie" (R). "Jy kan nie eens meer vir jouself klere maak nie en jy kan ook nie bekostig om te koop nie, dis maar moeilik in die dae"(R).

\section{Rol van psigofortigene faktore}

Die vraag is in watter mate psigofortigene faktore tot hierdie lewenstevredenheid van die bejaardes bydra. Die konstrukte wat deel vorm van Antonovsky $(1997,1987)$ se koherensiesin, te wete 'verstaanbaarheid', 'hanteerbaarheid' en 'betekenisvolheid' is vir hierdie doel gebruik as ' $n$ verwysingsraamwerk vir die ontleding van die transkripsies.

\section{Verstaanbaarheid van die eie lewen- situasie}

Antonovsky (1979) definieer 'verstaanbaarheid' as die mate waarin 'n persoon ervaar dat stimuli wat afkomstig is vanuit sy of haar eksterne en interne omgewing in die daaglikse lewe, gestruktureerd, voorspelbaar en gelykmatig is. Die bejaardes met Alzheimer se siekte in hierdie ondersoek het uiteraard probleme hiermee ervaar vanweë die kognitiewe inperkings wat reeds aanwesig was. Derhalwe was 'n geordende leefwêreld, ook geskep deur 'n roetine, vir hulle belangrik: "Ja, ek het vanoggend ' $n$ hele ent gestap hier na die winkelsentrum toe en ek het my goedjies gekoop, toe is dit etenstyd, toe het ek gaan lê en slaap en toe wou ek nou net my goedjies begin wegpak" (A).

Vir die bejaardes met rumatoïede artritis maak 'n begrip van die siekte en van die effek van die medikasie die situasie verstaanbaar: “... die pyntablette drink ek nie elke dag nie, net as ek weet, soos nou dat ek nie 'n bediende het nie en dis al die skottelgoed, potte en panne, dan drink ek maar 'n pynstiller of twee, dan gaan ek die dag deur' (R).

Van die pasiënte het ook ' $n$ baie sterk geloof in die wil van God in hul lewens. Hul geloof dat God hulle lewe beheer, lei daartoe dat elke dag as georden waargeneem kan word: "Weet jy, ek glo toe ek die dag gebore is, het die Here my pad vir my beplan. Hy het geweet waarlangs Hy vir my lei en as persoon dink ek nie ek kan iets daaraan doen nie, wat oor my kom dit voel ek, het die Here mee 'n doel waarom Hy dit doen" (R).

Op kognitiewe vlak help die pasiënte se lewensfilosofieë hulle in ' $n$ begripsvorming en ordening van die daaglikse gebeure. Hierdie lewensfilosofieë verskaf riglyne van hoe elke situasie hanteer behoort te word, wat dus ' $n$ mate van voorspelbaarheid van die situasie bewerkstellig. Dit kan trouens ook tot die ervaring van sinvolheid bydra: "Mens moet nooit te gou gaan sit nie, jy weet, as jy eers gaan sit dan dink jy jy kan nou niks meer doen nie ... 'n mens moet ' $n$ belangstelling hê, dit is wat ek natuurlik glo, mens moet belangstelling hê, ek is lief vir brei en bak, dit maak die lewe sinvol jy weet, jy sien dat jy darem kan" (R).

Ook die gesonde bejaardes se aanpassing is afhanklik van hulle begrip (verstaan) van die situasie: "Ek kan regtig nie kla nie, die susters is almal baie goed vir ons en, hm, dit is nou nie soos wanneer jy jou eie huis het, maar dit moet ons ook nou maar verstaan. Dit kan nie nou meer so wees nie" (G). 


\section{Hanteerbaarheid van eie lewensituasie}

Die kern van die hanteerbaarheidskomponent is die wete dat die nodige hulpbronne beskikbaar en onder die beheer van die persoon self of van belangrike ander is (Antonovsky, 1979, 1987).

Alzheimer se siekte lei tot ' $n$ verlies van outonomiteit. Elkeen van hierdie pasiënte het dus tot ' $n$ mindere of ' $n$ meerdere mate versorging nodig. Hierdie versorging word in ' $n$ tehuis vir bejaardes gebied soos blyk uit die volgende aanhaling: "... dis die ideale plek vir oumense om te bly ... ons het 'n siekeboeg hier, as iets verkeerd is, dan kan ons net siekeboeg toe gaan" (A).

Die gesinslede se ondersteuning word ook waardeer: "Herman, hy is ' $n$ wonderlike kind vir my gewees ... dan sê hy: 'Mamma moet nie bekommer nie, ek sorg vir jou'. Dan los ek dit net, ek los dit tot my seun kom, dan sê ek vir hom: 'Draai vir my die bottel oop of doen dit of doen dat', wat ek nie kan doen nie, help hy my mee, jy weet as hy kom, sal hy my kom help" (A).

Kaufman (1986) se siening dat sosiale ondersteuning as emosionele buffer dien wat aan die persoon die wete verskaf dat hulpbronne beskikbaar is in stresvolle lewensituasies, word dus bevestig.

Die pasiënte vergelyk hulself met ander bejaardes, meestal met bejaardes wat meer beperkinge as hulself ervaar. Hierdie proses lei tot die positiewe evaluering van hul eie gesondheid en dra dus by tot die positiewe emosionele belewenis van eie beheer: "... maar wat hierdie klomp hierso, is net sulke ou goed soos ek, jy weet, opgeroes en ek dink partykeer, ek onthou beter as party van hulle" $(\mathrm{A})$.

Hierdie bevinding is in ooreenstemming met die teorie van Salovey, Rothman, Detweiler en Steward (2000:110121) wat postuleer dat positiewe affek ontlok kan word deur jouself te vergelyk met ander wat slegter daaraan toe is. Dit bring mee dat die persoon beter oor hom- of haarself voel en die positiewe affek wat daarmee saamgaan verskaf die nodige sielkundige hulpbronne om sy of haar siektetoestand doeltreffender te hanteer.

\section{Betekenisvolheid van eie lewensituasie}

Die betekenisvolheidselement van die koherensiesin dui op die motiveringskomponent daarvan. Dit verwys na die mate waarin die lewe op emosionele wyse, eerder as kognitiewe wyse, sin maak. Dié komponent dui op eise wat ' $n$ uitdaging daarstel en wat ' $n$ emosionele verbintenis tot die uitdaging die moeite werd maak, selfs in moeilike tye (Antonovsky, 1979, 1987).

By die bejaardes was daar nie verwysings na lewensuitdagings nie, eerder ' $n$ stille berusting in hulle situasie. Die meerderheid van die pasiënte ervaar hul geheue en gesondheid as baie goed, wat hulle in staat stel om betrokke te bly in die besluitnemingprosesse van hul lewe: "Ek is baie dankbaar dat ek so gesond is soos wat ek is,... ek brei en hekel nog en maak somtyds rokke" (A).

Caplan (1990) se teorie word dus ook bevestig, naamlik dat dit nie noodwendig die neem van groot en ingrypende besluite is wat die gevoel van outonomie versterk nie, maar die alledaagse besluite oor lewensaktiwiteite. Die oorvleueling tussen die komponente van die koherensiesin word ook duidelik. Die voorafgaande aanhaling sou ook betrekking kon hê op die beheerbaarheidskomponent.

Die geloof in die teenwoordigheid van God in die ondersoekgroep se lewe dra daartoe by dat die lewe op 'n emosionele vlak sin maak: "Ek wil net sê, die Here is baie goed vir my ... ek het nog baie om voor dankbaar te wees" (A). Hierdie geloof verskaf vir vele van die bejaardes 'n bron van sekuriteit: "Die Here het my gemaak en ek is so. Ek is deur my lewe gelei en as ek dink hoe wonderbaarlik 'n mens gelei word. Jy word beskerm en as dit nie Genade van Bo is nie" $(\mathrm{A})$.

Uit bostaande blyk dit reeds dat Antonovsky se konstruk 'koherensiesin' ' $n$ betekenisvolle rol in die lewens van die bejaardes van hierdie ondersoekgroep speel. Hierdie bevinding verleen dus legitimiteit aan die konstruk.

\section{Relativering van die siekte}

' $n$ Vraag is egter of daar nie ook ander faktore is, bo en behalwe die elemente van ' $n$ koherensiesin, wat ' $n$ psigofortigene rol in die lewens van die bejaardes speel nie. ' $n$ Opvallende verskynsel by die bejaardes met Alzheimer se siekte sowel as dié met rumatoïede artritis was, in die verband, die neiging tot die relativering van hul siektes. Die neiging is bespeur om die siektes as iets 'apart' van hulle gesondheid in die algemeen te sien. Die manlike deelnemer met Alzheimer se siekte 
het gemeld dat sy geheue net nie meer so goed is nie, maar dat hy net gou vir sy vrou vra as hy iets wil onthou. Daarmee was hy tevrede. ' $n$ Bejaarde met rumatoïede artritis het weer gesê: “...ek dink nie, ek glo nie die artritis is my grootste probleem nie, my hande voel styf en warm en seer en die knoppe is bietjie pynlik en so, maar ek steur my nie baie aan die artritis nie" (R). ' $\mathrm{n}$ Ander bejaarde het dit só uitgedruk: "Man, met my gesondheid gaan dit eintlik goed, behalwe as dit onweer is, dan is my vingers bietjie seer, maar nie so erg dat ek nie my werk kan doen nie..." (R).

Die onderskeid wat getref word tussen die indekssiekte en die res van hul gesondheid help die bejaardes skynbaar om 'n positiewe opvatting oor hulle gesondheid te handhaaf ten einde steeds hulle dagtaak te kon voltooi. Die opvatting van Antonovsky (1987) word dus bevestig dat ' $n$ goeie gesondheidsbeeld gehandhaaf kan word deur die probleem te isoleer en 'buite' te plaas.

\section{Voorbeeld van 'n negatiewe geval}

Ten einde die vertrouenswaardigheid van bogenoemde waarnemings te toets is spesiale aandag aan die uitlatings van ' $n$ relatief ongelukkige bejaarde gegee. Van die 14 bejaardes in hierdie ondersoek was daar net een (met rumatoïede artritis) wat op interpersoonlike vlak relatief onvergenoegd voorgekom het. Haar ongelukkige kinderjare en versteurde familieverhouding speel klaarblyklik 'n oorsaaklike rol hierin. Daar is reeds voorbeelde gegee oor hoe sy kla dat sy niks kan bekostig nie. Tog meld sy: "Ek moet vir baie dinge dankbaar wees". "Die Here het my gemaak en ek is so. Ek is deur my lewe gelei en as ek dink hoe wonderbaarlik 'n mens gelei word. Jy word beskerm en as dit nie genade van Bo is nie, jy kan jouself nie beskerm nie".

Die feit dat selfs die bejaarde wat haarself van die ander onderskei het in terme van haar onvergenoegdheid, wel blyke van dankbaarheid en relatiewe tevredenheid toon, bevestig die lewenstevredenheid wat die ondersoekgroep as geheel demonstreer.

\section{Rol van weerstandshulpbronne}

Die vraag kom na vore watter faktore op hulle beurt weer die faktore onderliggend aan sielkundige sterktes onderlê. Antonovsky (1979) beklemtoon in hierdie verband die belangrike rol van weerstandshulpbronne by die handhawing van ' $n$ koherensiesin. Die belangrikste weerstandhulpbronne wat in hierdie ondersoek na vore gekom het was klaarblyklik die bejaardes se dankbaarheid vir goeie gesondheid, ongeag hulle siektes, die ondersteuning van gesinslede, familie en vriende en hul geloof in God. Die fasiliteite van die aftree-oord en tehuis vir bejaardes word ook as van besondere waarde geag soos uit van die voorafgaande aanhalings geblyk het.

\section{BESPREKING EN GEVOLGTREKKING}

Die indruk het dus na vore gekom dat feitlik al die bejaardes, ongeag hulle onomkeerbare inperkende siektes, 'n relatiewe hoë mate van lewenskwaliteit openbaar. Voortdurende spontane verwysings na ' $n$ waardering vir eie outonomie, die vermoë om nog dinge self te kan doen en die waarde van ' $n$ sosiale ondersteuningsnetwerk dui op 'n eudaimoniese lewenskwaliteit soos beskryf deur Ryan en Deci (2001:141-166). Hierdie lewenskwaliteit word ook deurgaans gekenmerk deur ' $n$ tevrede terugskou op die verlede en ' $n$ waardering van die huidige situasie. Verwysings na toekomsverwagtinge is egter opvallend afwesig. Dit is egter te wagte by ' $n$ bejaarde ondersoekgroep (Potgieter, 2003). Die aanvaarbaarheid van die voorgestelde definisie van lewenskwaliteit word dus wel gedeeltelik bevestig.

Die bevinding dat hierdie bejaardes oor die algemeen deur ' $n$ relatief hoë vlak van lewenskwaliteit gekenmerk word, bevestig Ryan en Deci (2001:141-166) se paradoks van veroudering en die resultate van verskeie ander navorsers in hierdie verband (Carstensen, 1998:341-346; Diener \& Lucas, 2000:325-337; Mroczek \& Kolarz, 1998:1333-1349; Ryff, 1989:195-210; Ryff, 1991:286-295; Ryan \& La Guardia, 2000:145-172).

Die komponente wat Antonovsky (1979, 1987) identifiseer as die grondslag van ' $n$ koherensiesin, speel kennelik ' $n$ groot rol in die ervarings van die bejaardes in hierdie ondersoek. Die waarde van Antonovsky se teorie word dus duidelik geïllustreer. Die noue verwantskap tussen die komponente van die koherensiesin blyk ook uit die aanhalings waar dieselfde aanhaling op meer as een komponent betrekking kan hê. Dit is ook duidelik dat weerstandshulpbronne wat die sterkste figureer, die bejaardes se sosiale 
ondersteuningsnetwerk en hulle spirituele ervarings is. Dit bevestig Antonovosky (1979, 1987), Csikszentmihalyi en Patton (1997:167-190), Masten (1994:3-25), Ryan en Deci (2000:68-78) en Ryff en Singer (1998:1-28;2000:30-44) se standpunte in hierdie verband.

Dit is vir die debat oor die filosofiese aard van sielkundige welstand van belang om daarop te let hoe ineengestrengel die hedonistiese en eudaimoniese elemente van hierdie bejaardes is. Hulle geluk of welstand lê meestal op die vlak van 'n gevoel van tevredenheid dat hulle uit die lewe gekry het wat hulle wou, dat hulle hul eie aard kon realiseer, dat hulle behoeftes dus bevredig is (verlede) en tans bevredig word (hede). Dit bevestig Ryan en Deci (2001:141-166) se siening omtrent die oorvleueling van die begrippe. Die idiosinkratiese, multidimensionele en kultuurspesifieke aard van welstand (Ryan \& Deci, 2001:141-166) kom ook veral na vore in hierdie bejaardes se waardering vir spirituele geloof en belewenisse, asook die fasiliteite wat ' $n$ aftree-oord of ouetehuis bied.

Dit is egter duidelik dat doelwitbereiking nie meer ' $n$ sterk motiverende krag uitoefen op hierdie bejaardes nie, maar dat daar by hulle eerder ' $n$ terugskouende tevredenheid is ten opsigte van doelstellings wat wel bereik is. Die beklemtoning in die voorgestelde omskrywing van lewenskwaliteit van die najaging van 'n doel in die lewe en van hoop as elemente van lewenskwaliteit, word dus skynbaar by die bejaarde gerelativeer. Die belangrikheid van die waarheidsgehalte van dit wat die mens nastreef, blyk egter uit die klem wat hierdie bejaardes op spirituele ervarings plaas en ondersteun die sieninge van Myers (2000:56-67) en Schwartz (2000:79-88).

\section{AANBEVELINGS VIR VERDERE NAVORSING}

Ofskoon hierdie studie grootliks die bestaande navorsingresultate op hierdie terrein ondersteun, is daar steeds ' $n$ behoefte aan omvangryker en meer gefokusde navorsing om die dinamika van die onderliggende prosesse duideliker te ondersoek. 'n Skerper differensiasie tussen die hedonistiese en eudaimoniese formulering van welstand op praktiese vlak kan ondersoek word. Die impak van 'n toekomsperspektief by die bejaarde op sy of haar lewenskwaliteit kan ook met vrug verder ondersoek word.

\section{BRONNELYS}

AMERICAN PSYCHIATRIC ASSOCIATION 1994: Diagnostic and statistical manual of mental disorders; $4^{\text {th }}$ edition. Washington, DC: APA Press.

ANTONOVSKY, A 1979: Health, stress and coping. New perspectives on mental and physical well-being. San Francisco: Jossey-Bass.

ANTONOVSKY, A 1987: Unravelling the mystery of health: How people manage stress and stay well. San Francisco: JosseyBass.

BEARE, J \& MYERS, H 1994: Principles and practice of adult health nursing. St Louis, Missouri: Mosby-Year.

BERG, BL 1995: Qualitative research methods for the Social Sciences. London: Allyn \& Bacon.

CAPLAN, AL 1990: The morality of the mundane: Ethical issues arising in the daily lives of nursing home residents. (In: Kane, RA \& Caplan, AL eds. 1990: Everyday ethics. Resolving dilemmas in nursing home life. New York: Springer).

CARSTENSEN, LL 1998: A life-span approach to social motivation. (In: Heckhausen, J \& Dweck, C eds 1998: Motivation and selfregulation across the life-span. New York: Cambridge University Press, pp 341-346).

CSIKSZENTMIHALYI, M \& PATTON, JD 1997: Happiness, the optimal experience and spiritual values: An empirical study of adolescents.

Revue Quebecoise de Psychologie, 18:167-190.

DIENER, E \& LUCAS, RE 2000: Subjective emotional well-being. (In: Lewis, M \& Haviland, JM 2000: Handbook of emotions; $2^{\text {nd }}$ edition. New York: Guilford, pp 325-337).

DIENER, E; SAPYTA, JJ \& SUH, E 1998: Subjective well-being is essential to well-being. Psychological Inquiry, 9:33-37.

EDWARDS, CRW; BOUCHER, IAD; HASLETT, C \& CHILVERS, ER 1995: Principles and practice of medicine. Edinburgh: Churchill Livingstone.

GEORGE, LK 1984: The burden of caregiving: Center reports of advances in research (Vol 8). (In: Barlow, DH \& Durand, VM eds. 1984: Abnormal psychology. Dallas, Texas: American Health Publishing, $p$ 621).

GLANTZ, MD \& JOHNSON, JL 1999: Resilience and development: Positive life adaptations. New York: Kluwer Academic/Plenum. KAUFMAN, S 1986: The ageless self: Sources of meaning in late life. Madison: University of Wisconsin Press.

KUMPFER, KL 1999: Factors and processes contributing to resilience. The resilience framework. (In: Glantz, MD \& Johnson, JL eds. 1999: Resilience and development. Positive life adaptations. New York: Kluwer Academic/Plenum).

MASTEN, AS 1994: Resilience in individual development: Suc- 
cessful adaptation despite risk and adversity. (In: Wang, MC \& Gordon, EW eds 1994: Educational resilience in inner-city America. Hillsdale, NJ: Erlbaum, pp 3-25).

MILES, MB \& HUBERMAN, AM 1994: Qualitative data analysis. Thousand Oaks: London.

MYERS, DG 2000: The funds, friends, and faith of happy people. American Psychologist, 55:56-67.

MROCZEK, D \& KOLARZ, C 1998: The effect of age on positive and negative affect: A developmental perspective on happiness. Journal of Personality and Social Psychology, 75:1333-1349. NUD*IST 1999: Qualitative solutions and research (Pty) Ltd. Melbourne: La Trobe University.

PATTON, MQ 1990: Qualitative evaluation and research methods; $2^{\text {nd }}$ edition. Newbury Park: Sage.

POTGIETER, CJ 2003: Tydsperspektief as potensiële psigofortigene konstruk by die rouproses van versorgers van Alzheimer-pasiënte. Bloemfontein: Universiteit van die Vrystaat (Ph D-proefskrif).

RYAN, RM \& DECI, EL 2000: Self-determination theory and the facilitation of intrinsic motivation, social development, and wellbeing. American Psychologist, 55:68-78.

RYAN, RM \& DECI, EL 2001: On happiness and human potentials: A review of research on hedonic and eudaimonic well-being. Annual Review of Psychology, 52:141-166.

RYAN, RM \& LA GUARDIA, JG 2000: What is being optimized over development? A self-determination theory perspective on basic psychological needs across the life span.(In: QUALLS, SH \& ABELES, N eds 2000: Psychology and the aging revolution. Washington, DC: APA Books, pp 145-172).

RYFF, CD 1989: In the eye of the beholder: Views of psychological well-being among middle-aged and older adults. Psychological Aging, 4:195-210.

RYFF, CD 1991: Possible selves in adulthood and old age: a tale of shifting horizons. Psychological Aging, 6:286-295.

RYFF, CD \& SINGER, B 1998: The contours of positive human health. Psychological Inquiry, 9:1-28.

RYFF, CD \& SINGER, B 2000: Interpersonal flourishing: A positive health agenda for the new millenium. Personality and Social Psychological Review, 4:30-44.

SALOVEY, SE; ROTHMAN, AJ; DETWEILER, JB \& STEWARD, WT 2000: Emotional states and physical health. American Psychologist, 55:110-121.

SCHWARTZ, B 2000: Self-determination: The tyranny of freedom. American Psychologist, 55:79-88.

SELIGMAN, MEP \& CSIKSZENTMIHALYI, M 2000: Positive psychology: An introduction. American Psychologist, 55:514.

STRAUSS, A \& CORBIN, J 1998: Basics of qualitative research. Techniques and procedures for developing grounded theory. Thousand Oaks: Sage
STRÜMPFER, DJW 1995: The origins of health and strength: From "salutogenesis" to "fortigenesis". South African Journal of Psychology, 25:81-89.

STRÛMPFER, DJW 2003: Resilience and burnout: A stitch that could save nine. South African Journal of Psychology, 33:6979

VILJOEN, M 2000: Fortologiese dimensies by bejaardes met Alzheimer se siekte of rumatoïde artritis. Bloemfontein: Universiteit van die Vrystaat (M Sc-verhandeling).

WATERMAN, AS 1993: Two conceptions of happiness: contrasts of personal expressiveness (eudaimonia) and hedonic enjoyment. Journal of Personality and Social Psychology, 64:678-691. WHALLEY, D; MCKENNA, SP; DE JONG, Z \& VAN DER HEIJDE, D 1997: Quality of life in rheumatoid arthritis. British Journal of Rheumatology, 36:884-888.

WISSING, MP \& VAN EEDEN, C 1998: Psychological well-being: A fortigenic conceptualization and empirical clarification. (In: Schlebusch, L ed South Africa beyond transition: Psychological well-being. Proceedings of the $3^{\text {rd }}$ Annual Congress of the Psychological Society of South Africa, pp 379-393). 